\title{
The GnRH receptor and the response of gonadotrope cells to GnRH pulse frequency code. A story of an atypical adaptation of cell function relying on a lack of receptor homologous desensitization
}

\author{
Raymond Counis, Ghislaine Garrel, Jean-Noël Laverriere, Violaine Simon, \\ Christian Bleux, Solange Magre, Joëlle Cohen-Tannoudji
}

Physiologie de l'axe gonadotrope, Unité de Biologie Fonctionnelle et Adaptative, Université Paris Diderot-Paris 7, CNRS-EAC 4413, 4 rue Marie-Andrée Lagroua-Weill-Hallé, 75205 Paris cedex 13 (France)

\begin{abstract}
Brain control of the reproductive system is mediated through hypothalamic gonadotropin-releasing hormone $(\mathrm{GnRH})$ which activates specific receptors (GnRHR) present at the surface of the pituitary gonadotropes to trigger secretion of the two gonadotropins LH and FSH. A unique feature of this system is the high dependence on the secretion mode of GnRH, which is basically pulsatile but undergoes considerable fluctuations in pulse frequency pattern in response to endogenous or external factors. How the physiological fluctuations of GnRH secretion that orchestrate normal reproduction are decoded by the gonadotrope cell machinery to ultimately control gonadotropin release and/or subunit gene transcription has been the subject of intensive studies during the past decades. Surprisingly, the mammalian GnRHR is unique among G protein-coupled receptor family as it lacks the carboxy-terminal tail usually involved in classical endocytotic process. Accordingly, it does not desensitize properly and internalizes very poorly. Both this atypical intrinsic property and post-receptor events may thus contribute to decode the GnRH signal. This includes the participation of a network of signaling pathways that differently respond to GnRH together with a growing amount of genes differentially sensitive to pulse frequency. Among these are two pairs of genes, the transcription factors EGR-1 and NAB, and the regulatory factors activin and follistatin, that function as intracellular autoregulatory feedback loops controlling respectively LH $\beta$ and FSH $\beta$ gene expression and hence, LH and FSH synthesis. Pituitary gonadotropes thus represent a unique model of cells functionally adapted to respond to a considerably fluctuating neuroendocrine stimulation, from short individual pulses to sustained GnRH as observed at the proestrus of ovarian cycle. Altogether, the data emphasize the adaptative reciprocal complementarity of hypothalamic GnRH neurones and pituitary gonadotropes to function as an original unit.
\end{abstract}

Key words: GnRH, GnRH receptor, GnRH receptor structure, signaling network, gene activation-inactivation

\section{Introduction}

The hypothalamic decapeptide gonadotropin-releasing hormone $(\mathrm{GnRH})$ is the neurohormone that mediates brain control of the reproductive system. GnRH acts through a specific seven-transmembrane-spanning receptor (GnRHR) expressed at the surface of anterior pituitary gonadotropes to trigger the synthe-

Correspondence: R. Counis, Physiologie de l'Axe Gonadotrope, Biologie Fonctionnelle et Adaptative, CNRS-EAC 4413, Université Paris Diderot, Bâtiment Buffon, 4eme étage - Case courrier 7007, 4 rue MA Lagroua-Weill-Hallé - 75205 Paris cedex 13, France; tel.: 331572784 01, fax.: 331572784 14, e-mail: raymond.counis@univ-paris-diderot.fr sis and release of the two gonadotropins, LH and FSH, which in turn regulate gonadal gametogenesis and steroidogenesis. Accordingly, the mechanisms underlying both $\mathrm{GnRH}$ release and action have been the subject of intensive research during the past decades. GnRH is produced in neuronal cells bodies primarily located in the preoptic area of hypothalamus and is released in a pulsatile manner into the portal vasculature of the median eminence-pituitary stalk through which it reaches the pituitary gonadotropes. As the final output of a complex neuronal network, the GnRH neurons integrate a myriad of endogenous and external signals resulting in a fine-tuned modulation of the pulse frequency pattern [1]. Because the 
gonadotrope cell response is highly sensitive to these frequency fluctuations, this creates a unique mode of neuroendocrine regulation. Indeed, it is well established that marked modifications in GnRH pulse profiles account for the differential changes in LH and FSH secretion profiles over the course of the ovarian cycle. In particular, the midcycle gonadotropin surge which is essential for initiating ovulation results from an abrupt and considerable rise in the GnRH pulse secretion that is even maintained beyond the LH discharge [2-4].

Interestingly, GnRH pulse frequency also influences gonadotropin synthesis. Both LH and FSH are heterodimers resulting from the noncovalent association of a common $\alpha$ - and a specific LH $\beta$ - or FSH $\beta$ subunit and all three subunits are encoded by a single gene [5]. It is now established that low frequencies preferentially increase transcription of the FSH $\beta$ gene whereas higher frequencies favor the $\operatorname{LH} \beta$ and $\alpha$-subunit genes $[6,7]$. On the other hand, sustained GnRH causes a more or less rapid depletion of both FSH $\beta$ and LH $\beta$ mRNA due to transcription arrest associated with transcript degradation. Contrasting with $\beta$-counterparts, the $\alpha$-subunit mRNA levels remain essentially constant or even increases slightly for days [8-10]. These observations are consistent with current clinical studies showing that long-term administration of GnRH superagonists readily induced depletion of LH and FSH but increased free $\alpha$-subunit levels in the serum of treated patients [11]. How physiological fluctuations of GnRH pulse patterns or drastic pharmacological treatments are decoded by the gonadotrope cell machinery to ultimately alter gonadotropin secretion and/or gene transcription has generated substantial, constantly renewed interest. Internalization and homologous desensitization of the GnRHR has been repeatedly invoked to explain the repressive effects of sustained stimulation. However, this idea is not supported by the fact that some genes are rapidly inactivated while some others remain readily activated. Furthermore, princeps studies early suggested that the GnRHR only poorly internalized [12].

The discovery that the mammalian GnRHR has lost the carboxy-terminal tail that is usually involved in classical endocytotic process of $\mathrm{G}$ protein-coupled receptors (GPCR) and does not desensitize properly provides an opportunity to reconsider our current vision of the mechanisms by which gonadotropes decode GnRH pulse frequency. Herein, we speculate that the lack of GnRHR homologous desensitization should confer to gonadotrope cells a unique feature i.e. the ability to respond to short but also to prolonged exposures of GnRH through differential mobilization of a diversity of intracellular mechanisms.

\section{The GnRH receptor activates a network of signaling pathways and regulates a stream of genes differentially sensitive to GnRH pulse frequency}

It has long been established that the GnRHR belongs to the superfamily of GPCR (13]. In the pituitary gland it is expressed only in the gonadotropes [14]. Upon ligand binding, the activated GnRHR preponderantly couples with $\mathrm{G \alpha q} / 11$ and consequently stimulates phospholipase $\mathrm{C} \beta$ (PLC). This induces the generation of diacylglycerols and inositol-triphosphates (IP3) which are responsible for the activation of several protein kinase $\mathrm{C}$ (PKC) isoforms and mobilization of intracellular $\mathrm{Ca}^{2+}$, respectively. This process, in conjunction with the massive entry of $\mathrm{Ca}^{2+}$ through voltage-dependent or -independent channels, is primarily involved in acute gonadotropin release [15]. GnRH also induces activation of the mitogen associated protein kinase (MAPK) cascade through PKC to stimulate the expression of gonadotropin subunit genes $[16,17]$. Moreover, the GnRH-stimulated elevation of intracellular $\mathrm{Ca}^{2+}$ causes activation of the NO synthase type I (NOS I) cascade (NOS I/NO/soluble guanylate cyclase) resulting in a rapid production of cGMP $[18,19]$. GnRH can also generate cAMP, albeit maximal cAMP accumulation is much weaker and delayed as compared to cGMP. The mechanisms underlying activation of adenylate cyclase in gonadotropes have long remained obscure. Recent data suggest the contribution of novel PKC isoforms in this process [20] in addition to the direct coupling through Gos [21]. Cyclic AMP stimulates the expression of LH subunit genes as well as the release of newly synthesised LH [22-24]. Collectively, these data indicate that GnRH induces a complex network of intracellular signaling pathways with different kinetics to activate or inhibit gonadotrope functions.

In addition, we and others have demonstrated that $\mathrm{GnRH}$ action on the gonadotropes is associated with an increasing complexity regarding gene regulation and cell function. Indeed, gonadotropin subunit genes are far from being the only genes affected by GnRH. Instead, a still growing number of additional genes has been identified using classical or more recent approaches such as high throughput screening [25]. Several of these genes are members of the GnRHR signaling network. These include, notably, the GnRHR itself $[10,26]$, NOS I [27,28], PKA [29] and PKC [30] isoforms as well as transcription factors such as ATF3 [31], NUR77 [32] and EGR-1 [24], or autocrine/ paracrine factors such as activin and follistatin. Regulation of these genes by GnRH appeared to be mediated through two or more signaling pathways. Unexpectedly, a majority of these genes are extremely dependent on GnRH pulse frequency as mentioned above for the gonadotropin $\beta$ subunit genes. For 
instance, the GnRHR gene responded better to relatively high $\mathrm{GnRH}$ frequencies, in the range of those required for $\operatorname{LH} \beta$ activation whereas a rapid although incomplete inactivation was observed at higher frequencies or under sustained GnRH stimulation [10,33]. In contrast, a few genes among which are the prototypic $\alpha$ subunit and the most recently identified NOS I, exhibited resistance to the inhibitory effects of protracted $\mathrm{GnRH}$ [27], further strengthening the idea that robust and/or prolonged stimulation of gonadotrope cells do not rapidly lead to a general cell desensitization. The fact that GnRH regulates most of its signaling entities in a manner highly dependent on the pulse frequency code is one of the key mechanisms allowing the appropriate adaptation of gonadotrope responsiveness.

\section{Evidence that the lack of a C-terminal tail confers an unusual resistance to internalization and desensitization of the mammalian GnRHR}

While molecular cloning has confirmed that the mammalian GnRHR possessed the structural features of classical GPCRs, it also revealed a striking difference, the lack of a cytoplasmic C-terminal tail [34]. Indeed, this intracellular extension, present in all other GPCRs, is a target for GPCR kinases allowing the recruitment of $\beta$ arrestin that initiates the endocytic processing of receptor/ligand complex via clathrin-coated pits $[35,36]$. Interestingly, the non-mammalian GnRH receptors which have been discovered later, do exhibit a C-terminal tail with structural and functional characteristics shared by the GPCR family [34,37]. The comparison of the internalizing properties of these two types of GnRHR either in normal pituitary tissues or in heterologous cell systems demonstrated that the C-ter possessing GnRHR internalized more rapidly and to a much greater extent than those lacking a tail. Moreover, adjunction of a C-terminal tail derived from any nonmammalian GnRHR or other GPCR readily restored internalizing properties to mammalian GnRHR [38,39]. All these studies were based on detection of labeled GnRH interacting with native or chimeric GnRHR. More recently, similar investigations were conducted using an epitope-tagged receptor allowing the direct analysis of the receptor molecule. This novel approach established that the mammalian GnRHR exhibits a low level of internalization either in absence or presence of GnRH, demonstrating the occurrence of a weak, constitutive agonist-independent internalization [40]. The notion that mammalian GnRHRs do not internalize and desensitize in response to ligand binding is further reinforced by studies from McArdle's group showing that a $\beta$-arrestin-green fluorescent protein fusion protein expressed in gonadotrope cells cannot undergo translocation from cytoplasm to membrane after activation of the mammalian GnRHR [41].

\section{Decoding the GnRH pulse frequency code through the mammalian GnRHR}

The mammalian GnRHR thus appears as an atypical GPCR able to confer hormonal selectivity and signal transduction to gonadotropes while not exhibiting internalization. This creates a peculiar situation in which post-receptor mechanisms are predominantly concerned in interpreting the wide range of $\mathrm{GnRH}$ pulse frequencies. In particular, one can speculate that at least some of the GnRH activated genes may contribute to the dual process of activation/inactivation of gonadotropin secretion.

Two mechanisms for the regulation of the $\mathrm{LH} \beta$ and FSH $\beta$ genes have been described to date that support the above vision of GnRH action. Indeed, the deciphering of combinatorial codes of transcription factors regulating the promoter activity of gonadotropin subunit genes has assigned an important role to the nuclear phosphoprotein EGR-1 (early growth response protein-1) in gonadotrope-specific as well as GnRHinduced expression of the LH $\beta$ gene $[42,43]$. EGR-1, also known as NGFI-A (nerve growth factor-induced protein $\mathrm{A}$ ), acts in concert with the other transcription factors SF-1, the pituitary homeobox PITX and, at least in rodents, SP1, to regulate $\mathrm{LH} \beta$ promoter activity. Interestingly, while GnRH activation of the LH $\beta$ gene is mediated through the rapid induction of the Egr-1 gene, its inactivation is initiated under sustained stimulation through the delayed rise of EGR-1 co-repressor NAB (NGFI-A binding) proteins, NAB1 and NAB2 [44,45]. Contrasting with Nab1, Nab2 expression is readily amplified as EGR-1 increases due to the presence of multiple EGR-1 elements within its gene promoter. This suggests that NAB2 is the most important EGR-1 regulator, crucial for establishing the negative feedback loop involved in the $\mathrm{GnRH}$ regulation of LH $\beta$ transcription [46]. Fig. 1 illustrates the counteracting effects of such sequential induction of $\mathrm{Egr}-1$ and $\mathrm{Nab}$ genes on LH $\beta$ expression, emphasizing the progressive induction of NAB proteins as the frequency of the GnRH stimulation is increased, leading to complete inactivation of $\mathrm{LH} \beta$ under prolonged GnRH exposure. A rather similar system based on the sequential activation of another couple of functionally complementary genes, i.e. activin and follistatin, has been described in the rat for $\mathrm{FSH} \beta[7,47,48]$. In this species, GnRH at low frequencies durably enhanced FSH $\beta$ gene expression via induction of the activin gene. By contrast, higher frequencies induced the co-expression of the follistatin gene leading to the neutralization of activin by follistatin thereby turningoff the GnRH stimulatory effects on FSH $\beta$.

These two examples well illustrate the manner by which the profile of GnRH secretion may differentially affect LH or FSH expression with a transcription decline for both $\beta$-subunit genes in response to 
A

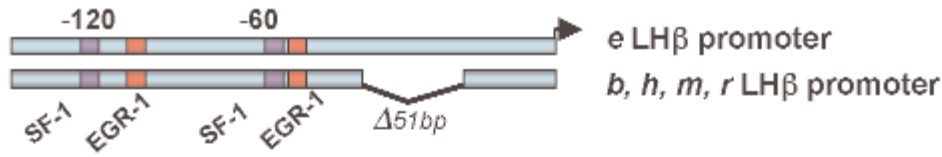

$B$

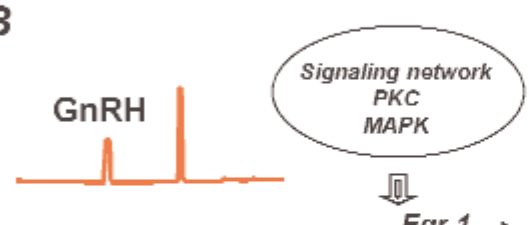

Egr-1
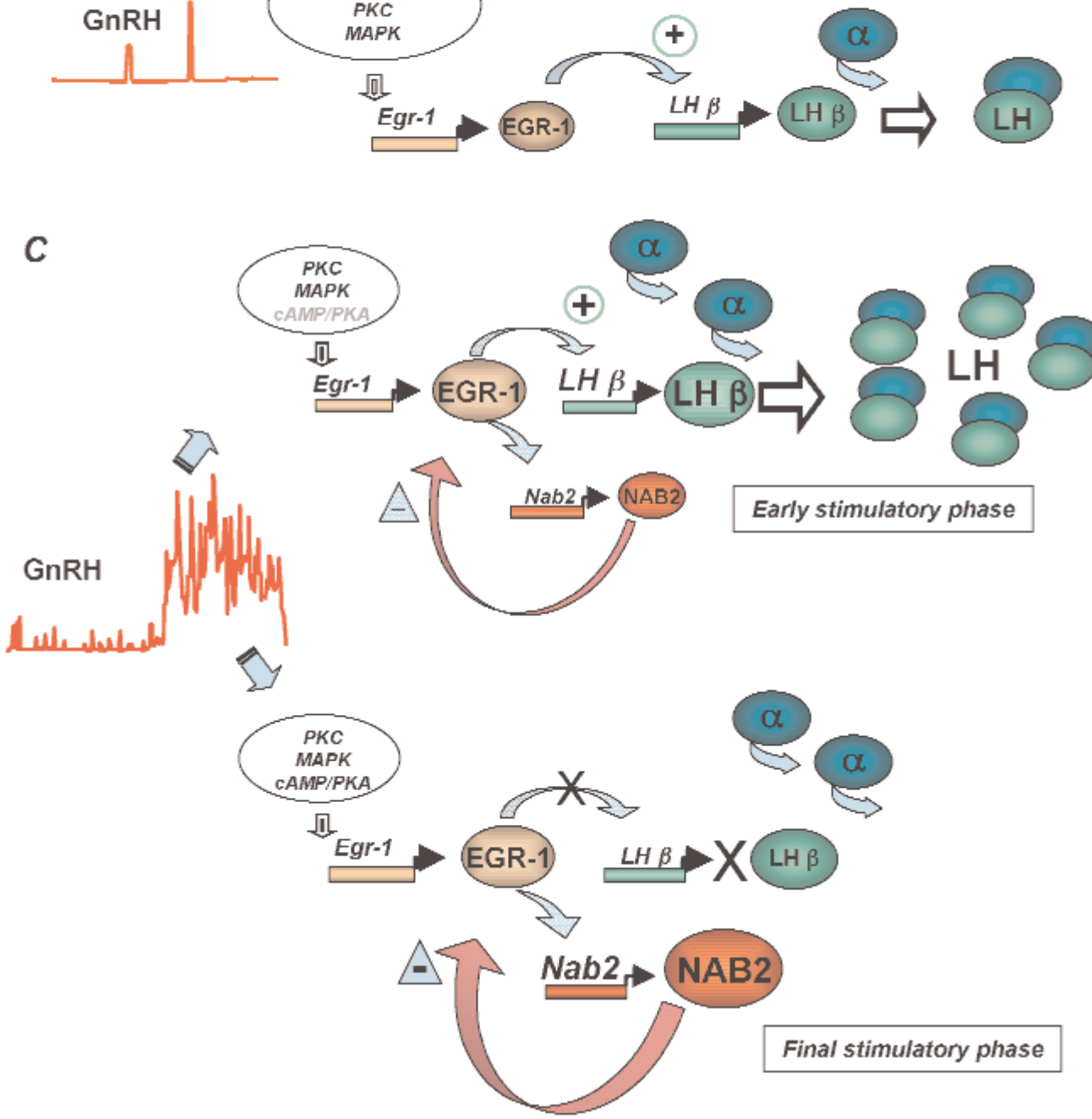

Fig. 1. Proposed model for neurohormonal regulation of the LH beta gene: an autoregulatory feedback loop feedback loop based on selective activation of Egr-l and Nab genes mediates the high sensitivity of LH $\beta$ gene expression to the GnRH pulse frequency code. A. Schematic representation of the proximal 140-bp region of the LH $\beta$ gene promoter illustrating in different mammalian species the positional conservation of two EGR-1 elements in tandem with two SF-1 (steroidogenic factor-1) elements. $e$, equine; $b$, bovine; $h$, human; $m$, mouse, $r$, rat. $\Delta 51$, sequence deletion in base pairs. B-C: Differential mechanisms for GnRH action depending on changes in the pulse frequencies. B. Short individual GnRH pulses. GnRH transiently stimulates gonadotropes leading to the rapid PKC/MAPK-mediated activation of the primary target gene Egr-1. The resulting immediate production of EGR-1 factor is sufficient to induce, in concert with other members of the transcription code, a weak transactivation of the LH $\beta$ gene associated with a modest LH $\beta$-subunit production and thus, generation of the $\alpha / \beta$ LH dimer. In this pulsatile mode, suppression of GnRH is sufficient to reset promoter activity to basal level during the interpulses. C. Robust and prolonged GnRH stimulation typified by proestrus of the ovarian cycle. Initially, highly repetitive GnRH pulses cause strong stimulation of the Egr-1 gene with a consequent high production of EGR-1 protein. This results in a robust stimulation of the LH $\beta$ gene promoter and an ensuing marked production of LH as transcription and synthesis of the $\alpha$-subunit is not limitating in gonadotropes. The ongoing GnRH stimulation induces a delayed activation of the Nab1 and Nab2 genes, leading to the progressive accumulation of the EGR-1 corepressors NAB proteins. NAB proteins dimerize with EGR-1 through conserved domains leading to neutralization of the EGR-1 transactivating potency. Interestingly, in contrast to Nab1, Nab2 expression is readily amplified as EGR-1 levels increase because the Nab2 gene promoter contains multiple EGR-1 cis-elements. This peculiarity confers to NAB2 a crucial regulatory role in the negative feedback loop depicted in the figure. Compared to the "early stimulatory phase" where EGR-1 production is predominant, the predominance of NAB ultimately leads to complete neutralization of EGR-1. This results in abolition of the stimulatory effects of EGR-1 on the LH $\beta$ gene ("final stimulatory phase"). In this system, the cAMP pathway would be preferentially operative in inactivation processes. 
increasing $\mathrm{GnRH}$ frequencies but with a distinct threshold of sensitivity as mentioned earlier.

Interestingly, several genes including Egr-1 can be activated in gonadotropes through multiple signaling systems, i.e. PKC, MAPK as well as the cAMP/PKA pathway [24]. Such a complex signaling could reflect redundancy or may be necessary for a coordinate regulation of cell functions. As mentioned above, while the former two pathways respond very rapidly to GnRH the latter, i.e. the cAMP/PKA pathway, reacts more progressively. This strengthens the idea that the cAMP/PKA signaling pathway would be preferentially operative under sustained GnRH stimulation. Moreover, cAMP can indirectly induce NAB2 since it stimulates Egr-1 promoter activity [24]. All the PKC, MAPK and cAMP/PKA transduction systems can thus potentially either activate or inhibit the LH $\beta$ gene depending on the modalities of GnRH stimulation. In contrast to the EGR-1/NAB2 system, the follistatin gene appears to be most specifically activated through cAMP/PKA [49].

Altogether, these complex regulatory systems suggest the functional predominance within gonadotropes of specific autoregulatory negative feedback loops composed of genes differentially sensitive to GnRH pulse frequency thus conferring a high dependence of LH and FSH on the GnRH stimulatory code. Whether similar systems also contribute to regulate expression of gonadotropin genes or others such as the GnRHR gene remains to be established.

\section{Conclusion}

The pecular mode of secretion of hypothalamic GnRH, together with the unusual structure and functional properties of the mammalian GnRHR defines a unique mode of intercellular communication as well as endocrine or neuroendocrine regulation. Indeed, the gonadotrope cells are exposed to considerably variable GnRH stimulations (from short to massive and even sustained) that profoundly and differentially affect gonadotropin release and gene regulation. The fact that these actions are mediated through a desensitizationresistant receptor implies the exclusive contribution of post-receptor mechanisms to achieve not only the secretory functions of gonadotropes but also the appropriate resistance of these cells to overstimulation which could lead to excessive secretion and hence, cell death. Taking into account these considerations, the function of gonadotrope cells appears surprisingly well adapted. The two models known to date for the activation/inactivation of gonadotropin $\beta$-subunit genes are exemplary of such dual functionality. The transcription factors EGR-1/NAB on the one hand, the regulatory factors activin/follistatin on the other hand, constitute two distinct, specific autoregulatory loops for the LH $\beta$ and FSH $\beta$ genes, respectively. In both systems, one partner (EGR-1 or activin) is responsible for activation, while the second (NAB or follistatin) is responsible for inactivation of a third partner gene (LH $\beta$ or FSH $\beta$ ). In fine, the situation emphasizes the adaptative reciprocal complementarity of both hypothalamic GnRH neurons and pituitary gonadotropes to function as an original unit mediating brain control of the reproductive system.

\section{References}

[1] Knobil E. Neuroendocrine control of the menstrual cycle. Recent Prog Horm Res. 1980;36:53-88.

[2] Sarkar DK, Chiappa SA, Fink G, Sherwood NM. Gonadotropin-releasing hormone surge in pro-oestrous rats. Nature. 1976;264:461-463.

[ 3] Xia L, Van Vugt D, Alston EJ, Luckhaus J, Ferin M. A surge of gonadotropin-releasing hormone accompanies the estradiol-induced gonadotropin surge in the rhesus monkey. Endocrinology. 1992;131:2812-2820.

[4] Caraty A, Antoine C, Delaleu B et al. Nature and bioactivity of gonadotropin-releasing hormone $(\mathrm{GnRH})$ secreted during the GnRH surge. Endocrinology. 1995;136:3452-60.

[ 5] Counis R. Gonadotropin synthesis. In: Neill J, Knobil E, eds. Encyclopedia of Reproduction. Vol.2. Acad. Press; 1999:507520.

[ 6] Dalkin AC, Haisenleder DJ, Ortolano GA, Ellis TR, Marshall JC. The frequency of gonadotropin-releasing hormone stimulation differentially regulates gonadotropin subunit messenger ribonucleic acid expression. Endocrinology. 1989;125:917-924.

[ 7] Burger LL, Dalkin AC, Aylor KW, Haisenleder DJ, Marshall JC. GnRH pulse frequency modulation of gonadotropin subunit gene transcription in normal gonadotropes - Assessment by primary transcript assay provides evidence for roles of GnRH and follistatin. Endocrinology. 2002;143:3243-3249.

[ 8] Lalloz MRA, Detta A, Clayton RN. Gonadotropin-releasing hormone desensitization preferentially inhibits expression of the luteinizing hormone $\beta$-subunit gene in vivo. Endocrinology. 1988;122:1689-1694.

[ 9] Rodin DA, Lalloz MRA, Clayton RN. Gonadotropin-releasing hormone regulates follicle-stimulating hormone $\beta$-subunit gene expression in the male rat. Endocrinology. 1988; 125:1282-1289.

[10] Lerrant Y, Kottler ML, Bergametti F, Moumni M, BlumbergTick J, Counis R. Expression of gonadotropin-releasing hormone $(\mathrm{GnRH})$ receptor gene is altered by $\mathrm{GnRH}$ agonist desensitization in a manner similar to that of gonadotropin $\beta$ subunit genes in normal and castrated rat pituitary. Endocrinology. 1995;136:2803-2808.

[11] Lahlou N, Roger M, Chaussain J, et al. Gonadotropin and alpha-subunit secretion during long-term suppression by DTrp6-luteinizing hormone releasing hormone microcapsules as treatment of precocious puberty. J Clin Endocrinol Metab. 1987;65:946-953.

[12] Hazum E, Cuatrecasas P, Marian J, Conn PM. Receptor mediated internalization of fluorescent gonadotropin-releasing hormone by pituitary gonadotropes. Proc Natl Acad sci USA. 1980;77:6692-6695.

[13] Andrews WV, Staley DD, Huckel WR, Conn PM. Stimulation of luteinizing hormone (LH) release and phospholipid breakdown by guanosine triphosphate in permeabilized pituitary gonadotropes: antagonist action suggests association of 
a $\mathrm{G}$ protein and gonadotropin-releasing hormone receptor. Endocrinology. 1986;119:2537-2546.

[14] Granger A, Ngô-Muller V, Bleux C, et al. The promoter of the rat $\mathrm{GnRH}$ receptor gene directs the expression of the human placental alkaline phosphatase reporter gene in gonadotrope cells in the anterior pituitary gland as well as in multiple extrapituitary tissues. Endocrinology. 2004;145:983-993.

[15] Stojilkovic S, Reinhardt J, Catt KJ. Gonadotropin-releasing hormone receptors: structure and signal transduction pathways. Endocr Rev. 1994;15:462-499.

[16] Naor Z, Benard O, Seger R. Activation of MAPK cascades by $G$ protein-coupled receptors: the case of gonadotropin-releasing hormone. Trends Endocrinol Metab. 2000;11:91-99.

[17] Sundaresan S, Colin IM, Pestell RG, Jameson JL. Stimulation of mitogen-activated protein kinase by gonadotropin-releasing hormone: evidence for the involvement of protein kinase C. Endocrinology. 1996;137:304-311.

[18] Ceccattelli S, Hulting AL, Zhang X, Gustafsson L, Villar M, Hökfelt T. Nitric oxide synthase in the rat anterior pituitary gland and the role of nitric oxide in regulation of luteinizing hormone secretion. Proc Natl Acad Sci USA. 1993;90:1129211296

[19] Lozach A, Garrel G, Lerrant Y, Bérault A, Counis R. GnRHdependent up-regulation of nitric oxide synthase I level in pituitary gonadotrophs mediates cGMP elevation during rat proestrus. Mol Cell Endocrinol. 1998;143:43-51.

[20] Lariviere S, Garrel G, Simon V, et al. Gonadotropin-releasing hormone couples to 3',5'- cyclic adenosine-5'-monophosphate pathway through novel protein kinase $\mathrm{C}$ delta and -epsilon in LßT2 gonadotrope cells. Endocrinology. 2007;148:10991107.

[21] Liu F, Usui I, Evans LG, et al. Involvement of both G(q/11) and $\mathrm{G}(\mathrm{s})$ proteins in gonadotropin-releasing hormone receptor-mediated signaling in L beta LBT2 cells. $J$ Biol Chem. 2002;277:32099-32108.

[22] Starzec A, Jutisz M, Counis R. Cyclic adenosine monophosphate and phorbol ester, like gonadotropin-releasing hormone, stimulate the biosynthesis of luteinizing hormone polypeptide chains in a nonadditive manner. Mol Endocrinol. 1989;3:618-624.

[23] Starzec A, Moumni M, d'Angelo-Bernard G, Lerrant Y, Jutisz M, Counis R. Cyclic AMP enhances gene expression, synthesis and release of newly synthesized $\alpha$ and luteinizing hormone $\beta$ subunits in cultured rat anterior pituitary cells. $\mathrm{Neu}$ rochem Int. 1989;15:259-264.

[24] Horton CD, Halvorson LM. The cAMP signaling system regulates LH $\beta$ gene expression: roles of early growth response protein-1, SP1 and steroidogenic factor-1. J Mol Endocrinol. 2004:32:291-306

[25] Kakar SS, Winters SJ, Zacharias W, Miller DM, Flynn S. Identification of distinct gene expression profiles associated with treatment of LbetaT2 cells with gonadotropin-releasing hormone agonist using microarray analysis. Gene. 2003;308:67-77.

[26] Kaiser UB, Jakubowiak A, Steinberger A, Chin WW. Regulation of rat pituitary gonadotropin-releasing hormone receptor mRNA levels in vivo and in vitro. Endocrinology. 1993;133:931-934.

[27] Garrel G, Lerrant Y, Siriostis C, et al. Evidence that gonadotropin-releasing hormone stimulates gene expression and levels of active nitric oxide synthase type I in pituitary gonadotrophs, a process altered by desensitization and, indirectly, by gonadal steroids. Endocrinology. 1998;139:21632170.

[28] Bachir LK, Garrel G, Lozach A, Laverriere JN, Counis R. The rat pituitary promoter of the neuronal nitric oxide synthase gene contains an Sp1-, LIM homeodomain-dependent enhancer and a distinct bipartite gonadotropin-releasing hor- mone-responsive region. Endocrinology. 2003;144:39954007.

[29] Garrel G, Lerrant Y, Ribot G, Counis R. Messenger ribonucleic acids for alpha- and beta-isoforms of cyclic adenosine 3',5'-monophosphate-dependent protein kinase subunits present in the anterior pituitary: regulation of RII beta and C alpha gene expression by the cyclic nucleotide and phorbol ester. Endocrinology. 1993;133:1010-1019.

[30] Harris D, Reiss N, Naor Z. Differential activation of protein kinase $\mathrm{C} \delta$ and $\varepsilon$ gene expression by gonadotropin-releasing hormone in $\alpha \mathrm{T} 3-1$ cells. Autoregulation by protein kinase C. J Biol Chem. 1997;272:13534-13540.

[31] Xie J, Bliss SP, Nett TM, Ebersole BJ, Sealfon SC, Roberson MS. Transcript profiling of immediate early genes reveals a unique role for activating transcription factor 3 in mediating activation of the glycoprotein hormone $\alpha$-subunit promoter by gonadotropin-releasing hormone. Mol Endocrinol. 2005; 19:2624-2638.

[32] Hamid T, Malik MT, Millar RP, Kakar SS. Protein kinase A serves as a primary pathway in activation of Nurr77 expression by gonadotropin-releasing hormone in the L $\beta \mathrm{T} 2$ mouse pituitary gonadotroph tumor cell line. Int $J$ Oncology. 2008;33:1055-1064

[33] Yasin M, Dalkin AC, Haisenleder DJ, Kerrigan JR, Marshall JC. Gonadotropin-releasing hormone $(\mathrm{GnRH})$ pulse pattern regulates GnRH receptor gene expression : augmentation by estradiol. Endocrinology. 1995;136:1559-1564.

[34] Millar RP, Lu ZL, Pawson AJ, Flanagan CA, Morgan K, Maudsley SR. Gonadotropin-releasing hormone receptors. Endocr Rev. 2004;25:235-275.

[35] Ferguson SS, Barak LS, Zhang J, Caron MG. G protein-coupled receptor regulation: role of $\mathrm{G}$ protein-coupled receptor kinases and $\beta$-arrestins. Can J Physiol Pharmacol. 1996;74:1095-1110.

[36] Lefkowitz RJ. G protein-coupled receptors. III. New roles for receptor kinases and $\beta$-arrestins in receptor signaling and desensitization. J Biol Chem. 1998;273:186673-18680.

[37] Lethimonier C, Madigou T, Munoz-Cueto JA, Lareyre JJ, Kah O. Evolutionary aspects of GnRHs, GnRH neurohormonal systems and GnRH receptors in teleost fish. Gen Comp Endocrinol. 2004;135:1-16.

[38] Davidson JS, Wakefield IK, Millar RP. Absence of rapid desensitization of the mouse gonadotropin-releasing hormone receptor. Biochem J. 1994;300:299-302.

[39] Pawson AJ, Katz A, Sun YM, et al. Contrasting internalization kinetics of human and chicken gonadotropin-releasing hormone receptors mediated by $\mathrm{C}$-terminal tail. J Endocrinol. $1998 ; 156: R 9-R 12$.

[40] Pawson AJ, Faccenda E, Maudsley S, Lu ZL, Naor Z, Millar RP. Mammalian type I gonadotropin-releasing hormone receptors undergo slow, constitutive, agonist-independent internalization. Endocrinology. 2008;149:1415-1422.

[41] McArdle CA, Franklin J, Green L, Hislop JN. Signalling, cycling and desensitisation of gonadotropin-releasing hormone receptors. J Endocrinol. 2002;173:1-11.

[42] Kaiser UB, Halvorson LM, Chen MT. Sp1, steroidogenic factor 1 (SF-1), and early growth response protein 1 (Egr-1) binding sites form a tripartite gonadotropin-releasing hormone response element in the rat luteinizing hormone- $\beta$ gene promoter: an integral role for SF-1. Mol Endocrinol. 2000;14:1235-1245

[43] Topilko P, Schneider-Maunoury S, Levi G, et al. Multiple pituitary and ovarian defects in Krox-24 (NGFI-A, Egr-1)-targetted mice. Mol Endocrinol. 1998;12:107-122.

[44] Wolfe MW, Call GB. Early growth response protein 1 binds to the luteinizing hormone- $\beta$ promoter and mediates gonadotropin-releasing hormone-stimulated gene expression. Mol Endocrinol. 1999;13:752-763. 
[45] Lawson MA, Tsutsumi R, Zhang H, et al. Pulse sensitivity of the luteinizing hormone $\beta$ promoter is determined by a negative feedback loop involving early growth response- 1 and Ngfi-A binding protein 1 and 2. Mol. Endocrinol. 2007;21:1175-1191.

[46] Kumbrink J, Gerlinger M, Johnson JP. Egr-1 induces the expression of its corepressor Nab2 by activation of the Nab2 promoter thereby establishing a negative feedback loop. J Biol Chem. 2005;280:42785-42793.

[47] Besecke LM, Guendner MJ, Schneyer AL, Bauer DA, Jameson JL, Weiss J. Gonadotropin-releasing hormone regulates follicle stimulating hormone-beta gene expression through an activin/follistatin autocrine or paracrine loop. Endocrinology. 1996;137:3667-3673.
[48] Dalkin AC, Haisenleder DJ, Gilrain JT, Aylor K, Yasin M, Marshall JC. Gonadotropin releasing hormone regulation of gonadotropin subunit gene expression in female rats: actions on follicle-stimulating hormone beta messenger ribonucleic acid (mRNA) involve differential expression of pituitary activin (beta-B) and follistatin mRNAs. Endocrinology. 1999;140: 903-908.

[49] Winters SJ, Ghooray D, Fujii Y, Moore Jr JP, Nevitt JR, Kakar SS. Transcriptional regulation of follistatin expression by $\mathrm{GnRH}$ in mouse gonadotrope cell lines: evidence for a role for cAMP signaling. Mol Cell Endocrinol. 2007;271:45-54. 